\title{
EVALUATION OF HYBRID THREATS TO DU TECHNOLOGIES TRANSFER
}

\author{
Iegor Kartuzov ${ }^{l}$ \\ ${ }^{1}$ Department of Political Science, European Studies Unit, University of Liege, Liege 1, Belgium \\ E-mail: iegor.kartuzov@student.uliege.be \\ ORCID: http://orcid.org/0000-0001-7493-674X
}

ARTICLE INFO

ABSTRACT

Article history:

Received date 16.11.2021

Accepted date 09.12.2021

Published date 30.12.2021

An object of this research is to evaluate the premises of transfer of dual use technologies

Section:

Technology transfer appeared in Ukraine and other CIS countries. It aims to highlight a hybrid impact of political, historical and other potential barriers faced between technology offeror/recipient nowadays. The investigated problem. Apart from the highlighted affect of political, historical and other potential barriers faced between technology supplier/recipient these days, the paper also DOI discusses how the covid pandemic and democracy crisis on the global joined to and affect

$10.21303 / 2313-8416.2020 .002220$ an efficiency, proper functioning and transparency of technology transfer process. The experience and practice show that the process of technology transfer is rather complicated,

KEYWORDS

export control

technology transfer

dual use technologies

covid pandemic multi-leveled and involves more than two players. It is impacted with and follows few factors and conditions that constrain its success or failure at the end. It was shown that the development of dual use technologies continues in a quagmire of conflicting interests, in light of discussed factors therein, national security and export control rationales. For the time being, debates on dual use (DU) technologies and their misuse lack creativity and rather dim; political and diplomatic initiatives came finally to nowhere trying to find turnkey solutions, thus the discussed set of factors affecting the efficient transfer and strategic export control, is quite a challenge nowadays.

The main scientific results. The discussed therein factors imply the hybrid threat to transfer of technologies, closely interrelated and possess a profound significance, tho. From today and forward each step towards optimization of transfer should be carried out considering all groups and specifics of high level of science intensity of advanced technologies. Ukraine being a country with still transitional (from socialist to capitalist) type of economy, a mechanism for IP protection with regard to their scientific and technical results providing this necessary level of science intensity of technology, in the analyzed period of time has not yet been properly worked out and not enshrined in bylaws.

The result of thi research makes a solid background for further debates as to technology transfer in terms of political science and export control.

(C) The Author(s) 2021. This is an open access article under the Creative Commons CC BY license

\section{Introduction}

\section{1. Object of research}

An object of this research is to evaluate the premises of transfer of dual use technologies appeared in Ukraine and other CIS after a collapse of the USSR. It aims to highlight a hybrid impact of political, historical and other potential barriers faced between technology offeror/recipient nowadays. The paper also discusses how the covid pandemic and democracy crisis on the global contributed into and affect an efficiency and transparency of technology transfer process.

\section{2. Problem description}

Factors implying a threat to technology transfer may be divided into four main groups:

1) political;

2) legal;

3) social/cultural (mental);

4) technical.

In reality, all those are so interrelated that sometimes it is impossible to clearly determine which one this factor belongs to, and to assess its impact on technology transfer not accounting for its relationship and interweaving with others. From the point of effectiveness of implementation 
of transfer of dual-use technologies in Ukraine, a profound significance and nature of each group of factors differ. The final success determinants are groups of political and mental factors since they are more mobile in time, meanwhile legal and technical ones are well documented for a rather long period of time. Indeed, fixed provisions adopted under certain political and mental situation (earlier) cause problems with changes in political and mental factors nowadays. These changes are quite kaleidoscopic in Ukraine and other CIS, therefore, let's review more "stable" groups of factors first.

\section{3. The problem in question}

Previous works [1-3] devoted to evaluation and succinct analysis of premises affecting transfer of technologies in Ukraine highlight that DUs' status quo implies that global economy undergoes democracy crisis and number of changes related to demographic trends, technological advances, accelerated innovation and globalization. All this led to the fact that today there is a significant need to increase a level of entrepreneurship in Ukraine, which also plays a critical role in improving a steady growth of economy and national security. Development of technologies and transfer of those contribute to the improvement of state's technological advantage, which significantly increases the level of nation's well-being and leads GDP to an increase. The barriers that entrepreneurs and transferors face [4-6] are mostly bureaucratic and to arrive at greater effect, it is necessary to reduce those to the maximum.

That is why, the aim of this endeavor is to highlight a hybrid impact of political, historical and other barriers faced between technology supplier/recipient nowadays and to debate on how the COVID pandemic and democracy crisis joined it and "contributed" into the technology transfer process.

\section{Methods}

As above stated, it is to scrutinize factors being staying in between technology supplier/ recipient as well as future prospects and real steps of tomorrow. A study employs qualitative methodology and is found under an umbrella of a descriptive research profile to agree on historical, technical, political, and mental barriers for technology transfer. This descriptive research portrays a rather accurate profile of current situation around Ukrainian technology transfer. Its' design offers a profile of described relevant aspects of the problem of interest from author's individual perspective.

\section{Results and discussion}

\section{1. Technical and legal factors}

Literally, a technology transfer [7] is the transfer of technological achievements from one legal / physical entity to another. The Ukrainian Law ("On State Regulation of Activities in the field of Technology Transfer" dated of 09/14/2006 - hereinafter referred to as the Law) [8], where a term "technology transfer" is explained in Article 1 Basic Definitions as follows: technology transfer is a transfer of technology, which is executed by concluding among physical and/or legal entities a bilateral or multilateral agreement that establishes, changes or terminates property rights and obligations regarding the technology and/or its components. Getting deeper to an issue of technology transfer, at least at the beginning two parties are primarily involved, - an offeror and recipient. Nevertheless, since one may choose the "official" button for "a method of technology transfer", then the third player immediately steps in - a State represented by intelligence service guys and export control. Export control is an integral part of state's national security and performs its duties in accordance with legislation and international non-proliferation obligations adopted by Ukraine. In terms of security, the export control system prioritizes ensuring national security interests, and in terms of economy, creating favorable long term conditions for development of economy and society. At the same time, a development of technologies exacerbates strong contradictions between economic interests of exporting enterprises, that is, the interests of economic development and those of national and international security. International transfer of goods either strategic or not may be divided into three stages - preparation for transfer, transfer itself and procedures for preand post-delivery of goods. State export control procedures are applied at each indicated stage of international transfer. These technical and legal factors affecting technology transfer are developed 
by the international community and do not require any special comments. They are officially accepted and reflected in the Ukrainian appropriate legal documents, nevertheless an implementation of those in real life, due to a transformation of political and mental driving forces, brought a profound collapse of transfer of dual-use technologies in Ukraine. Therefore, let's analyze a transformation of political and mental factors while Ukraine stepping from a position of key Soviet Union republic to a sovereign "independent” European country.

\section{2. Political and mental driving force}

Social and cultural factors (mental, historical) form a way of living, working, thinking, consuming and significantly impact on all areas of activity (scientific, political, etc., even technology transfer) in a state. It is also aggravated and supplemented by a historical factor (country's evolution), which has an important role in society's sociality and mentality. New trends of life and competition create a new type of thinking of scientists, businessmen, politicians, etc. According to the famous physicist M. Bourne: "science has become a matter of national importance ... Science has become an integral and most important part of our civilization, and scientific activity directly affects the development of civilization" [9]. Legislative and state factors influence opportunities and threats to technology transfer and national and foreign officials can be key regulators here. This means that an assessment of political environment may be the most important aspect for technology transfer. The evaluation is made through a refinement of political and legal factors affecting it. Many factors and even more combinations of those exist; thus, let's single out and list the most common: an alignment of political forces, a relationship between business and government, patent law, government regulation, political conditions in global, a relationship of present government with foreign states, changes adopted in tax laws and customs service, etc.

It is indisputable that innovation successes in Ukraine mainly due to former R\&D results to ensure industrialization and development of the defense industry of the former USSR. Therefore, seems it would be quite logical to begin an analysis of transformation of political and mental factors from the very first years of existence of Ukraine as an independent state. This initial period of transition to the world market economy was, firstly, under the precise scrutiny of the world community, and secondly, under construction of competent transition strategy for the CIS (where Ukraine held one of the leading positions in development of advanced materials science technologies), which involved top level professionals who at that times sincerely believed in what they were doing and wished a prosperity for the country, thirdly, when, in a flow of erupted democracy, a freedom of speech and publication still reigned. To understand the initial position of Ukraine (as part of the Soviet Union, which was called "Russia" throughout the world at that times), one may to recall two quotes. The author of the first quotation " father of the H-bomb in the USA" Dr. Edward Teller in 1957, after launching the first satellite in the USSR, said: "Ten years ago there were no doubts where the best scientists of the world have been gathered, of course, in the USA. In ten years, the best scientists in the world would be found in Russia as in the USSR, the science is almost a religion." In 1992, academician the National Academy of Sciences of Ukraine V. I. Trefilov was one of the main organizers of a quite big international forum in Strasbourg being held under the auspices of the European Material Science Community and for the first time ensured big international conference of materials science representatives from East and West (over 800 scientists, businessmen and politicians attended). From the former Soviet Union, more than 200 main specialists attended this conference; the event was accompanied by an exhibition in the field of latest R\&D results on advanced materials science technologies and aroused such a great interest in Western countries that even parliamentarians from France, Germany and other countries took part . At the opening remarks, a president of international material science community unexpectedly almost quoted Dr. E. Teller, saying: "we are pleased to welcome at our representative meeting a large squad of the former Soviet Union, a country where science was God".

However, no doubt that in the USSR, the science was of a prime state's priority, especially when it came to the issues of state security and defense systems. Since 1991, a deliberate transfer of results of these works to the West, began. The "Defense News" (March 1992) wrote, "Using Russian (literally Ukrainian) technologies with no analogues in the USA, in a space program would provide 10-fold reduction in fuel costs and lead to savings over the next three years about 100 million dollars. Research in the field of directed energy weapons in the United States would take about 
11 years with a cost of $\$ 1.9$ billion, and the use of Russian technologies would reduce it to six years and costs to $\$ 0.8$ billion".

"Pravda" (leading official newspaper of Russia) on January 25, 1995, wrote: "From the letter M 151/9-17434 dated of August 26, 1994, E. Primakov, head of the Foreign Intelligence Service and S. Stepashin, head of the Federal Security Service: "In general, the West acquired so many new technologies from Russia that NATO established a special program for their processing".

The experience of these years showed that in Ukraine the opportunities developed by science were not used to a full extent, although the initial conditions were unique since at that time Ukrainian President (Leonid Kuchma) [10] was the representative of the most science-intensive and progressive branch of modern science and technology - space rocket, where, literally, even a single step cannot be made without science and new technologies. The steps were taken and the following statements of leading experts made a strong witness indeed:

1) the head of Austrian space agency, who traveled around all countries with missile systems, wrote in the review book of the Yuzhnoye Design Office [11]: "I visited all launch sites of all countries all over the world and I did not see anything like "Zenit" (the missile system developed in the Yuzhnoye Design Office). This is the highest technical achievement of the twentieth century";

2) Western experts recall on technical excellence of SS-18 intercontinental ballistic missile, which in the West was called as "Satan": "SS-18 missile is one of the biggest and highly efficient systems of this type. A brilliant achievement of Soviet military technology";

3) in June 1998, The New York Times wrote about the "Sea Launch Program" [12]: "Ukrainian missiles are significantly superior to the US. The US Air Force recently adopted a missile, which engine, was designed according to the development of Russian (S. Korolev Rocket and Space Corporation Energeia) and Ukrainian specialists (Yuzhnoye State Design Office named after M. Yangel). "We have nothing like Russian engine manufacturing technologies," said Charles Wieck, expert at the Federation of American Scientists.

Leonid Kuchma in his inaugural speech stated that “... the acute imperative of our time: in fact, is to include a development of education, science, new technologies to the most important state priorities. To attribute the highest social values to intelligence, education, inner culture of a person".

At that times, the Committee for State Security (KGB) [13] suppressed an analysis of transformation of the highest echelon of power. The Communist Party was overthrown, yet a market economy required an order and strong state. This is evidenced by economic science and is being trumpeted by "new" cadres, who came to power. However, these cadres are not the second, but even rather third echelon of the same party functionaries, who were not the best representatives of school of administration trained by the Soviet Communist Party System. French economist E. Kine, analyzing CIS economies in his paper in the "Monde" (March 1993) stated: "... a volume of industrial production inevitably falls. With the exception of military-industrial complex, which is notable for its efficiency, but now located in a pen, chaos reigns in the economy. Planning was canceled, the authority of central government vanished, and nothing replaced it. The market economy requires order and a strong state, as evidenced by the experience of countries in Western Europe, Japan and the "new industrial states" of Southeast Asia. Otherwise, all attempts to adopt modern forms of management from other countries will be futile".

A creation of effective system of state governance is a matter of the highest professionalism in a quite bureaucratic system of Ukraine and its solution has nothing to do with the increase in the number of officials practiced by the "new rulers" on the body of our frail economy. In February 1996, at a seminar in Ivano-Frankivsk held under the auspices of the World Bank, the facts were cited according to which the number of officials in Ukraine increased from 280 thousand in 1991 to 510 thousand in 1995. In November 1996, the Wall Street Journal published an article by M. Brzezinski, who, summarizing the experience of international business in Ukraine, came to a conclusion that “... these bureaucrats are highly effective brake on a way of development of free market in the country ... If you are not strong enough and do not have lobbying abilities, you will be buried here". In Russia, Ukraine and other CIS countries a formation of domestic capital took place with strong violations of laws and direct participation of mafia and political party clans. Y. Baturin, assistant to the President of Russia for National Security, was forced to officially state ("Izvestia” Newspaper, October 14, 1995) "Economic crime is the most real threat to national security today. About 40 thousand enterprises 
of various forms of ownership are controlled by criminal clans. Bribed officials assist every fourth criminal gang. Sometimes bribes amount to hundreds of thousands of dollars".

This is a starting transformation of subfactor 1 - "the highest echelon of power". Let's move on to a subfactor 2 - "material support". All governments in the analyzed period (it should be mentioned that they replaced each other in a rather fast manner) stated that Ukraine does not have any means to implement a revival program. For a variety of reasons, huge emerging private capital has so far been sluggishly invested. Not the least role is played by the fact that this new private capital in a large number of cases is far from being of flawless origin and is in no hurry to come to light from the shadow. It should be noted that rather huge foreign investments were contributed into all countries of economic "miracle of revival" without any exception. Only in Western Europe (Germany) according to the Marshall Plan [14], about 15 billion USD was invested at the exchange rate of those years (by modern standards, approximately 60 billion USD), the industrial re-equipment of former GDR (being a part of state cost Germany almost 120-150 million Deutschmarks per year). Total foreign investment in so fast-growing China arrived nearly 500 billion USD. Investments in small Hungary exceeded 13 billion USD. Poland received approx. 4 billion USD in 1996. For the first 5 years of independence, Ukraine (as of 01/01/96) received about 750 million USD of investments [15] while the Ministry of Economy estimated that the minimum amount required was 4 billion USD (according to other estimates, the optimal amount of investment at that time required 200 billion USD). At that times, the industry destroyed by inflation suffered fantastic losses due to a breakdown of cooperative and financial ties with counterparts from the former Soviet Union, but so far it physically exists and has not been physically destroyed (as it was in Germany and Japan). Nevertheless, the existing flagships of high-tech industries (rocket industry, aviation, metallurgy, energy, and turbine construction) of the world scale are stifled by taxes, lack of working capital, prehistoric barter settlement system and extremely frustrated financial system.

The Academy of Sciences of Ukraine had a high and internationally recognized authority even against powerful Academy of Sciences of the USSR, forming the image of Ukraine as a powerful scientific and technical power in the world, especially in the field of materials science, genetics, rocket and other sciences. Nevertheless at this time, its' condition is deplorable and is drastically falling. It is a starting point of transformation of subfactor 2 (material support). The transformation of subfactor 3 - "Market" is to be illustrated by only one example.

First, let's highlight that world's experience shows that a whole complex pyramid for economic recovery based on production of high-quality competitive products is justified only if an appropriate market is formed. The above said subfactors (availability of advanced technologies, qualified personnel, etc.) are the required conditions and only a presence of the market (and confident position in it) is a sufficient condition and plays a profound significance for future success. Market demand, sales and market stability determine production volumes, government priorities and, ultimately, profit guaranteeing a prosperity.

Since dual-use technologies are those developed by civil R\&D public and private companies that can be transferred to/for military/weapon purposes, thus the main markets are civil and military ones. The short-term weakening of control over the arms market in tough years when the USSR fallen apart, resulted in loss of a significant part of this market. The quota of Russia (applied to Ukraine) was captured by the USA, France and other countries that constantly quarrel and challenge a comprehensive support of transformations in CIS. The last decade witnessed a series of brilliant expositions of Ukrainian weapon systems at many exhibitions held both domestically (the XVII International specialized exhibition Arms and Security - 2021) [16] and abroad (for example, the past and coming EUROSATORY 2022 [17]), delighted press reviews, and the highest evaluations from counterpart experts - yet, comparatively small sales, as the market was completely lost, and again it is very difficult task to get back on track.

As good examples a few quotes from publications of that time comes: 1) Ronald Graham (Director of the Bell Research Center at Murray Hill: "If you go to Harvard University, you will find out that Russian is the second language there. A similar situation is observed at the universities of Carolina and Berkeley and many others"; 2) Yurevich and Tsapenko wrote [18]: "According to the estimates of the heads of foreign scientific centers, the possibility of absorption of Russian scientists is exhausted only by $50 \%$. It is estimated that in the coming years, Western Europe and Israel will be able to accept 150-200 thousand Russian specialists, and Asia, Latin America, Aus- 
tralia, and Africa - 40-50 thousand. An increasingly active policy of luring our scientists through the organization of various competitions, internships, etc. Assimilation programs have been developed in China, South Korea, Brazil, Argentina, Mexico, Paraguay, which are particularly interested in high rank specialists in the military-industrial complex and dual-use technologies. In these conditions, we can assume that the current scale of intellectual emigration from Russia is "a tip of an iceberg" in comparison with what awaits us". It was a succinct definition of starting transformation of dominating political and mental factors in the first years of formation of Ukraine as an independent country with significant potential for transfer of advanced technologies. Academician V. I. Trefilov [19] and other leading scientists of that time proposed and brought to the government strategic and operational-tactical substantive plans for state's economic revival nevertheless, the government turned blind eyes and was deaf to all those propositions, and it was at that time, in the starting period. Thus, let's analyze how the transformation of political and mental factors has been developed and at what point they are at present.

In today's Ukrainian society, while implementing socio-economic reforms and transforming the existing system of power relations, a political elite is being periodically changed and more often even rotates each other thus, as a result, a vector of ruling elites to science as a whole often changes as well. As a result, starting from the day of independence, the vector chosen by Ukraine for the implementation of state policy in the field of science brought such a result that, in terms of financial support of R\&D efforts, neither in absolute value nor in dynamics can be comparable with the counterparts in the European countries. Ukraine is the only country that used almost three decades period of its own development not to increase financial allocations to domestic science, yet visa versa, which dynamics made minus $9.3 \%$ [20]. As a result, the loss of qualified scientific personnel, a decrease in the financing of scientific and scientific-technical works (SSTW). There is a constant fall in total number of employees of R\&D institutions and, most importantly, the number of specialists directly involved in SSTW. According to 1991-2021, no one may guarantee the exact number of highly qualified specialists and scientists who left Ukraine and still leaving. However, one may mean thousands of talented people. 89 years ago, Hares Jensen (1904-1971) political adviser to the chairman of the Social Democratic Labor Party of Sweden described this kinda situation and said: “...when scientists, engineers, doctors and other intellectuals leave the country. A color of nation - the intelligentsia - is leaving, then businessmen rule in such a country, and plebeians and swindlers from a street - politicians and market speculators, athletes and artists become parliament members" (from his speech at the Reichstag Committee on Migration and Demographic Policy, 1932). This could be definitely applied to all CIS at any temporary interval of their existence till even nowadays. It adds to the mental factor has an imperceptible, and often a decisive role in implementation of any reforms and state's policy.

Meanwhile also worth noting the established tendency for scientific and political elites to merge, as well as their mutual penetration. A problem of influence of scientists and scientific ideas on politics and vice versa is reduced to a formation of a certain mechanism of interaction between organizations of scientific and political elites. One of the most noticeable phenomena in Ukrainian science is the mass exodus of scientists into politics. Although the scale of this type of brain drain cannot be compared with its' two other types - an emigration of Ukrainian scientists abroad and their transition to business, in terms of its importance, all these types are quite comparable, having a great influence on science and politics. The reasons for a masse migration of scientists into politics are quite obvious. Since late 1990s, Ukraine has been experiencing a cult of politics and all that could be associated with it. Under these conditions, politics, where big money is concentrated (personal enrichment and a possibility of lobbying controlled fundamental scientific and R\&D programs and their subsequent financing from state programs and grants), serves as a natural center of attraction for active and ambitious people, because participation in a political life being associated with constant attention of mass media - a much better way to gain a prominence than a dozen of scientific books. Thus, for example, during the years of reformation of society, it was believed that a "Kitchener" cannot and should not lead a state (unlike figurative aphoristic wishes of Vladimir Lenin [21]), and "scientist" can and a must to do this. S. Kara-Murza expressed a view that, in philosophical terms, "Kitchener -scientist" dilemma means the problem of matching functions of state power and types of thinking. S. Kara-Murza highlights that the "Kitchener" symbolizes day by day thinking, which systematically, holistically, and morally evaluates a reality, but scientist 
personifies scientific rationality, process of modeling and experimentation, abstraction from moral values for the sake of truth. Therefore, political decisions must be made by a person with the thinking of the "Kitchener", and scientists can, at best, act as experts in politics [22].

It should be noted that in "troubled" 1990s, scientists who were close to country's steering wheel and highest political circles, did not treat former colleagues very sympathetically. Unlike others, they did not lobby for scientific interests and, visa versa, often acted against those.

The opposite phenomenon looks less understandable - politicians attraction to science. It is especially noticeable in CIS, where politics between political debates and battles, write "scientific" books, give lectures, and defend dissertations. There is also a strong desire of politicians to be "a famous and well-known guy" in various scientific academies (for example, former President of Ukraine (2010-2014) V. Yanukovych [23], Doctor of Economics and Professor was the head of the Northeast Scientific Center of the National Academy of Sciences of Ukraine, and the Prime Minister - N. Azarov, Corresponding Member of NASU in the field of "mountain geophysics"). Most of all, politicians and scientists are brought together by an indefatigable love for academic degrees and titles, which, in most cases, has a negative impact on development of science as a whole and lobbying its individual directions. As there are many of them who wants to change a "feather to the Monomakh's hat", than these hats exist, scientists often act not as politicians, but advisers, consultants and analysts. G. Kissinger, former the US Secretary of State wrote: "It is extremely rare for intellectuals to be found at the highest level of decision-making. Usually his/her role is advisory only". Charles de Gaulle once put it this way: "There is no need for a politician to possess Spinoza's mind, his/her "mind" is his/her advisers and analysts". Thus, from here comes the overgrowth of the highest executive power with serving expert apparatus, as well as similar processes that occur outside state power institutions - in parties, trade unions and other public organizations. It should be noted that in Ukraine and other countries of the former Soviet Union, there is no process worked out, and indeed any reasonable mechanism for bringing "brains" to power, the collections as "Who is who", if published, are not read either by politicians or by political environment, and a scientist can gain prominence in the Ukrainian society only by becoming a rich and well-known businessman or politician. The prospects for bringing a scientist closer to power in Ukraine are determined by four main factors. Firstly, the fame obtained as a result not of scientific merit, but of regular appearances in mass media. Secondly, with a loyalty to politicians. Thirdly, the penetrative abilities of intellectuals themselves - an ability to attract attention, push themselves closer to power and show the abilities similar to the main character of a very famous book "Parkinson's Law" Mr. Prolez possessed. And, fourthly, the ability to be at the right time in the right place, suggesting a special "flair" on what, where and when to do so that those who are in power may notice you. As a result, the model scientist who advises our politicians is a native of the "middle" layer of scientific community, an active candidate of science who has not gained special laurels in science, but who succeeded in self-promotion and become close to the mass media. It is quite believed that in politics are mainly coming those whose IQ is a bit above the average level, but not that high and achieve a success since those with too high intelligence are perceived by masses as aliens and incomprehensible [24]. By such objective indicators of scientific productivity as citation index and number of publications, scientists leaving for politics and business are four to five times inferior to their colleagues who remain in science, and $70 \%$ of such ex-scientists have never been quoted. In general, the facts show that those who leave a scientific battlefield, nothing tangible left there, of course, not only because of a lack of motivation, but a lack of an appropriate talent. This is another negative factor in a coalescence of politics and science, since it is precisely such "scientists" who are able to influence state policy in relation to science and its areas as a whole.

Two years ago, and who knows how far forward the global COVID crisis actively joined the considered factors and current state of Ukrainian economy have further reduced its demand for research. It is interesting to observe how the crisis conditions of politics in different countries are perceived differently. In developed countries, the state usually strengthens its support for science due to compensate a drop of effective demand for R\&D caused by the crisis. In Ukraine, visa versa it is believed that science is the first sphere in which budget funds can be saved most painlessly. The draft Law of Ukraine "On Amendments to the Law of Ukraine" On the State Budget of Ukraine for 2020 “(registration No. 3279 dated March 29, 2020) [25], implies a reduction by 300.0 million UAH the amount of funding for NASU under the budget program 6541230" Support for a development 
of priority areas of scientific research". Ukrainian scientists sent an open letter to the President of Ukraine and noted "that due to numerous lockdowns and underfunding, NASU research teams have been working part-time since the beginning of the covid pandemic thus an average employment per year decreased from 10.8 to 9.5 months. Today, under the threat of disruption, is an implementation of priority research and development, being selected on a competitive base and aimed at increasing the country's defense capability" [26]. The government's rat race against the covid pandemic contributes to impoverished Ukrainian scientists that would result in further brain drain and illicit transfer of technologies. A good example is the order 1096 [27] of the Cabinet of Ministers of Ukraine on suspension from work of unvaccinated employees without pay, which contradicts with the Constitution Law of Ukraine. Orders, resolutions, recommendations must comply with the law otherwise, they are criminal, unconstitutional and cannot be enforced. The paradox is that the executive branch issues orders against and ignores the legislature and the constitution. Unfortunately, one may observe democracy crises, violation of human rights in these volatile times at the global.

Thoughtless dragging of funds to accelerate an enrichment of oligarchic clans radically changed state's economic system where the high-tech component drastically decreased, namely this component in Ukraine and in most other countries is associated with a solvent demand for R\&D results. Therefore, the pompous motto "not just to look into the sky and think up something there, as it was in the $19^{\text {th }}$ century, but to work for the result" is at least sounds an inappropriate as of today. The fact is that, despite all faced troubles and difficulties, Ukrainian scientists still have very serious and competitive results and many of those were taken abroad sometimes illicitly.

Finally, let's conclude the analysis of factors threatening to transfer of technologies with another quote coming from a speech of ex-Prime Minister of Russia Sergey Kiriyenko at Harvard University, where he gave the invited lecture and formulated the main and insurmountable difficulty of his premiership: "The main conclusion is that in Russia there are no unsolvable economic problems, and there is only one problem - the problem of weakness of power (political factor) due to the lack of public consent (mental factor). In a democratic society, the power can be strong only if public opinion supports what it does. It is necessary to separate the formal authorities of power and moral ones. For example, when the last May, being on strike, miners laid on rails and blocked trains, the formal authority of power to sweep 'em from the rails by force - a lot. It is no problem there is a law and law enforcement agencies (police, etc.), nevertheless, when the miners rally $70 \%$ society's support and only $10 \%$ is left for the government, the government cannot use the formal power to take them away, this is absolutely impossible. So, in fact, happens with the whole problem of reform". In fact, Ukraine when gained the independence, entered an era of changes. "I wish you to live in era of changes" is a very famous ancient Chinese curse, indeed, not a wish, but curse: the Chinese like nobody else appreciated stability and rhythm. The changes, in their opinion, promise nothing good and, it seems, now we are ready to take it. The times (first "perestroika" in the former USSR, then gaining of "independence", and out of the blue - covid pandemic) in which we live could be described as rather "interesting" or the "era of changes." However, human beings are an adaptive creature, and adapts to absolutely any conditions although this Chinese expression sounds like the curse to many, there is some positive meaning: any crisis is the best time for new opportunities. In extreme conditions, a person might do something that in a common environment would never dare thus let's wait and see if to be or not a civilized transfer of high technologies in Ukraine - however with the advent of new administration still remains dim.

The result of this endeavor makes a solid background for further debates in terms of political science, legal regulations and export control associated with technology transfer. They highlight that DUs' status quo implies that a global economy undergoes, democracy crisis, a number of changes related to demographic trends, technological advances, globalization and it is affected with all those factors discussed therein.

\section{Conclusions}

The above discussed factors imply a hybrid threat to transfer of technologies, closely interrelated and possess a profound significance. From now and forward each step towards optimization of transfer of technologies should be carried out considering all groups and specifics of high level of science intensity of advanced technologies. Ukraine being a country with still transitional (from socialist to capitalist) type of economy, a mechanism for IP rights protection with regard to their 
scientific and technical results providing this necessary level of science intensity of technology, in the analyzed period of time has not yet been properly worked out and not enshrined in bylaws. The same fully applies to preferences and incentives for companies employing innovations in their products. The technical and legal factors for technology transfer domestically in form and content de facto have yet to be actually changed, despite its format is established and tightly oversighted by the international community on the basis of Ukraine's international obligations. Introduction of legally declared procedures used in the international transfer of advanced technologies (especially dual-use) has been rigidly blocked by a red tape at almost all levels of the executive branch. Unfortunately, Ukraine is the only country that used the period of its formation as a sovereign country not to increase budgetary financial allocations for national science, but to reduce those. This historical factor leads to a catastrophic change in the mental factor. As a result, there is a drastic fall of science priority and science-intensive GDP as well as a drastic brain drain among scientists and now thanks to the covid pandemic as well. For Ukraine with its powerful and internationally recognized, scientific and innovative potential, transfer of emerging technologies may play a role in resolving the most pressing problems of economic development and would contribute into a formation of powerful and prosperous European state thus the economic factor steps in that has not yet finally said its decisive word.

\section{Acknowledgements}

This effort and the research behind associated with the political science would not have been possible without the exceptional support of my supervisor, prof. Dr. Quentin Michel (Department of Political Science, European Studies Unit, University of Liege). His enthusiasm, knowledge and exacting attention to every detail have been an inspiration and kept my work on track from my very first encounter with political science and legislation referred particularly to transfer of dual use technologies in the EU and Ukraine. Also, I would like to express my deep thanks to my father Dr. Valeriy Kartuzov (Head of Department of Computer Modeling and Numerical Experiment in Materials Science, Frantsevich Institute for Problems in Materials Science, NASU) for fruitful debates and sharing his almost 50 years' experience gained in advanced materials and DU technologies.

\section{References}

[1] Kartuzov, I. (2021). An impact of political, historical and mental premises on dual-use technologies transfer in Ukraine. Technological and Scientific Innovation: Networks, Geography and Policy. Lisbon.

[2] Kartuzov, I. (2020). Dual-use material science technologies transfer in ukraine: premises and present catch-22. ScienceRise, 5, 95-102. doi: http://doi.org/10.21303/2313-8416.2020.001477

[3] Kartuzov, E. V., Quentin, M. (2019). Barriers in technology transfer of advanced DU materials in Ukraine. Bulletin of the Ukrainian Materials Science Society named after Academician I. M. Frantsevich, 12. Available at: http://www.materials.kiev.ua/ article/2955?sect_id=4

[4] Kartuzov, I. (2020). Evaluation of dual use materials science technologies issue in Ukraine - «trick or treat». Technology Audit and Production Reserves, 5 (4 (55)), 48-52. doi: http://doi.org/10.15587/2706-5448.2020.215489

[5] Kartuzov, I. (2018). Problems and difficulties appearing at transfer of technologies of production of dual-use materials. The Belt and Road Initiative. 2018 Qingdao International Technology Transfer Conference.

[6] Kartuzov, I. (2019). Dual Use Technologies in Materials Science (By the example of IPMS NAS of Ukraine). 2019 International Conference on the Cooperation and Integration of Industry, Education, Research, and Application. Harbin.

[7] Anykyn, A. V. (Ed.) (1981). English-Russian Dictionary of Economics. Moscow, 792.

[8] Pro derzhavne rehuliuvannia diialnosti u sferi transferu tekhnolohii (2006). Zakon Ukrainy No. 143-V. 14.09.2006. Available at: https://zakon.rada.gov.ua/laws/show/143-16

[9] Bourne, M. (1973). My life and views. Moscow: Progress Publ., 176.

[10] Leonid Kuchma. Available at: https://www.britannica.com/biography/Leonid-Kuchma

[11] Yuzhnoye. Available at: https://www.yuzhnoye.com/en/home/

[12] Sea Launch Program. Available at: https://yuzhmash.com/en/projects/sea-launch-program/

[13] KGB. Available at: https://www.history.com/topics/russia/kgb

[14] Marshall Plan, 1948. Available at: https://history.state.gov/milestones/1945-1952/marshall-plan

[15] Sobolev, V. M. (1999). Formirovanie rynochnoi infrastruktury v perekhodnoi ekonomike industrialnogo tipa: obschie cherty i osobennosti v Ukraine. Kharkiv: Biznes-inform, 304. 
[16] Report on the Results of the XVII International Specialised Exhibition Arms and Security (2021). Available at: https://www. iec-expo.com.ua/en/oren-2021.html

[17] EUROSATORY. Available at: https://www.eurosatory.com/?lang=en

[18] Iurevich, A. V., Tsapenko, I. P. (1998). Intellektualnaia emigratsiia iz Rossii. Vestnik RAN, 68 (7), 643-648.

[19] Skorokhod, V. V., Firstov, S. A., Kartuzov, V. V. (Eds.) (2005). V.I.Trefilov. Zhizn i deyatelnost. Vospominaniya. Izbrannye trudy. Kyiv: Academperiodika. Available at: http://www.nbuv.gov.ua/node/924

[20] Odotiuk, I. (2018). One step forward and two steps back - declarations and reality of the state policy for development of science, innovation and high-tech production in Ukraine. Economy of Ukraine, 2018 (10), 127-141. doi: http://doi.org/10.15407/ economyukr.2018.10.127

[21] Vladimir Lenin. Available at: https://www.biography.com/political-figure/vladimir-lenin

[22] Kara-Murza, S. (1995). Posle perestroiki. Intelligentsiia na pepelische rodnoi strany. Moscow, 98-99.

[23] Ianukovich Viktor. Available at: https://file.liga.net/persons/viktor-yanykovich

[24] Iurevich, A. V., Tsapenko, I. P. (2003). Nauka i politika. Priroda, 5. Available at: http://csr.spbu.ru/pub/RFBR_publications/ articles/social\%20sciences/2003/nauka_i_politika_03_hum.pdf

[25] Proekt Zakonu pro vnesennia zmin do Zakonu Ukrainy "Pro Derzhavnyi biudzhet Ukrainy na 2020 rik" (2020). Available at: http://w1.c1.rada.gov.ua/pls/zweb2/webproc4_1?pf3511=68570

[26] Uchenye obratilis k Prezidentu iz-za sokrascheniia finansirovaniia (2020). https://day.kyiv.ua/ru/news/070420-uchenyeobratilis-k-prezidentu-iz-za-sokrashcheniya-finansirovaniya

[27] Pro vnesennia zmin do deiakykh aktiv Kabinetu Ministriv Ukrainy (2020). Postanova Kabinetu Ministriv Ukrainy No. 1096. 11.11.2020. Available at: http://search.ligazakon.ua/1_doc2.nsf/link1/KP201096.html 